\title{
Investigating the Effects of Involvement on Consumer Decision
} Process

\author{
Seyed Fathollah Amiri Aghdaie ${ }^{1}$, Farhad sanaei ${ }^{2} \&$ Ali Akbar Abedi sharabiany ${ }^{1}$ \\ ${ }^{1}$ Departement Of management, University of Isfahan, HezarJarib, St. Darvazeh Shiraz, Isfahan, Iran \\ ${ }^{2}$ Department of management Payam-e-noor University, Varamin, Iran \\ Correspondence: Seyed Fathollah Amiri Aghdaie, Departement Of management, University of Isfahan, \\ HezarJarib, St. Darvazeh Shiraz, Isfahan, Iran. Tel: 98-311-793-5251. E-mail: s.aghdaie@ase.ui.ac.ir
}

Received: July 11, 2014 Accepted: September 18, 2014 Online Published: October 30, 2014

doi:10.5539/ass.v10n22p217 URL: http://dx.doi.org/10.5539/ass.v10n22p217

\begin{abstract}
The purpose of this study is to examine the effect of involvement on the consumer decision process. In this study, involvement includes individual, social, and behavioral factors. The statistical population of this study includes the customers that have purchased from BALL chain stores in the city of Isfahan in 2013. A sample of 300 customers has been selected for survey through random sampling method. Data-collecting instrument is a questionnaire. The results of this study indicate that there are significant positive relationships between involvement and consumer decision process. Also significant positive relationships have been observed between personal and behavioral factors with consumer decision process, but any significant relationship has not been observed between social factors and consumer decision process. The results of this study help the marketers to understand the consumers' behaviors so that implement appropriate strategies for their products and help their company to achieve its goals and survive in the nowadays competitive world.
\end{abstract}

Keywords: involvement, consumer decision process, consumer behavior

\section{Introduction}

Growth and development of markets in the nowadays competitive world leads to supply different products in the markets. The marketing managers need to develop strategies and provide marketing opportunities in order to deliver these products to their customers. In order to this, recognizing consumer behavior especially in purchase decision has effective role in promoting these strategies. The customers and buyers decision process for cheaper and everyday products is simple, but they should decide seriously for buying the expensive products which requires complex decision making process (Kotler, 1988). This process consists of five steps that includes recognizing need and identifying problem, exploring information, evaluating alternatives, purchasing, and after purchase behavior (Miniard et al., 1993; Puccinelli et al., 2009). The consumer facing different environmental factors in every step that includes (1) goals, schema, and information processing, (2) memory, (3) involvement, (4) attitudes, (5) affect, (6) atmospherics, and (7) consumer attributions and choices. (Puccinelli et al., 2009). The involvement is one of the important factors in the consumer buying decision (Goldsmith, 2002; Maoz \& Tybout, 2002; Mittal, 2004; Sengupta \& Fitzsimons, 2004; Shamdasani et al., 2001). Involvement is defined as an invisible mode of motivation, internal mobility, and interest (Rothschild, 1984) and refers to the extent that consumers interest on the products information (Zaichkowsky, 1985). The authors investigate the involvement in three sets including situational involvement, sustainable involvement, and responding the involvement. Situational involvement refers that the consumers concentrate on the impersonal factors about the objects and things that there are in a particular situation. Sustainable involvement refers to attracting the consumer's attention to the things and objects that are related to long term periods and also concentrate on the personal characteristics. Finally, responding the involvement refers to the mental condition that combine the situational and sustainable factors and then reflect as consumer decision process that is based on the cognitive and behavioral processes (Houston, Michael, \& Rothschild, 1978).

Zaichkowsky (1986) divide the involvement factors into three sets that include personal, motivational, and situational factors. The personal factors are about the needs, interests, and values of a particular subject. The motivational factors are related to the stimulus characteristics such as solutions differences, communications resources, and communications extent. The situational factors are related to the product purchase situations that 
lead to involvement. For example, the consumer attends the advertisements about car more than other products advertisements if he/she decides to buy a car. Zaykoski (1986) believes that each of the factors is related to the different involvements such as product, product purchase, and advertisements (Zaichkowsky, 1986).

Therefore, the purpose of this study is to examine the effect of involvement on the consumer decision process. Several studies have been done about involvement independently, but this study seeks to examine the involvement from three dimensions including personal, social, and behavioral factors. Each of these dimensions consists of different factors. For example, jealously is one of the social factors dimensions that has been examined in the social factors hypotheses. All in all, 17 factors are derived from these three factors that all of them have been examined in three secondary hypotheses.

\section{Conceptual Framework and Hypotheses}

\subsection{Consumer Decision Process}

Engel et al. (1968) developed the EKB model. This model assumes that the consumer decision process has a continuous process that leads to problem solving (Lin, \& Chen, 2006). Engel et al. (1993) report that, the center concept of the EKB model means consumer purchase decision processing, which is also problem-solving processing to consumer decision processing and includes five stages: demand confirmation, search for information, evaluation of alternatives, purchasing, and purchasing result.

The purchase type is effective in involvement. Involvement in the complex purchases situations is high, because these purchases force the consumers to acquire more information about product and then decrease their perceived risks (Grant, Clarke, \& Kyriazis, 2010). The buyers pass a process with five steps in their purchases decision (especially in the complex situation) so that purchase the product. The buyers recognize their needs or problems in the first step. They use different resources for acquiring information (such as personal, commercial, public, and empirical resources). They also evaluate the information in the third step. A purchase is done in the fourth step. Finally, the buyer or consumer may satisfy or dissatisfy with his/her purchase in the fifth step (Kotler, 1988).

\subsection{Consumer Behavior and Involvement}

It is not easy to understand the consumer behavior and customer recognition. The customers may express their needs and wants in a way and do in another way. They may do not understand their main motivations or respond the effective factors that can change their attitudes in the purchase time. Regardless of this, the marketers should examine their customers' wants, perceptions, purchase, and after purchase behaviors (Kotler, 1988). In the consumer behavior frame, involvement is a step that involve in different aspects that are related to the products, advertisements, and purchase (Zaichkowsky, 1986; Broderick \& Mueller, 1999). The empirical evidences show that the involvement level is indicator of the consumers' behavior diagram (Josiam, Kinley, \& Kim, 2005). High involvement in a product leads to high motivation in the consumer purchase behavior (Lianga, 2012) and also the product involvement has significant positive relationship with customer purchase decision (Lin, \& Chen, 2006). There are different factors that may have role in the consumer decision making. These include personal, social, and behavioral factors that can be examined in three hypotheses.

\section{H1: involvement influences the consumer purchase process.}

Personal factors: individuals' decision is influenced by their personal characteristics. These characteristics include buyer age, life cycle, occupation, income, educational level, personality, and personal perception. The young consumers' needs and wants are different from old ones and also involvement is more among young consumers than elders (Ocass, 2000). On the other hand, women's purchase is different from men's purchase in terms of conventional modes costs (Pentecost \& Andrews, 2010). The female consumers with low income are involved in common purchases and have not high loyalty to the household products (Gbadamosi, 2009). The educated consumers' preferred products and purchase are completely different from illiterate ones.

\section{H1-1: the personal factors influence the consumer purchase decisions positively.}

Social factors: the consumer behavior is influenced by different social factors such as reference groups, family, role, and status. The social influences are effective in the product involvement and also involvement level is influenced by social factors (Kuenzel \& Musters, 2007). Family members also influence each other's purchase perspective. The reference groups are effective in choosing the product such as relatives, friends, social organizations, and professional institutes. The customers that have high involvement with a particular product seek to purchase their products from which centers that offer them more information about the product (Kim, Kim, \& Park, 2010). Also because there are different alternatives for their choices and they have less time to evaluate their choices, they may listen to the opinion leader's viewpoints and also consider their attitudes and 
preferences in the purchase (Tammy, Bharath, \& Lockett, 2010, Tejavibulya \& Eiamkanchanalai, 2011). Everyone's position in every group depends on his/her social status. Buyer choices which products and services for purchasing that can reflect their social status and position. Additionally, some consumers (especially women) may do not attend the modes and also the empirical findings indicate that female consumers have high involvement in the dress modes than male ones (Ocass, 2000). Samz et al. indicate that involvement is a good predictor of the lox modes (Summers, Belleau, \& Xu, 2006) and also jealously may actuates the consumers toward buying different products.

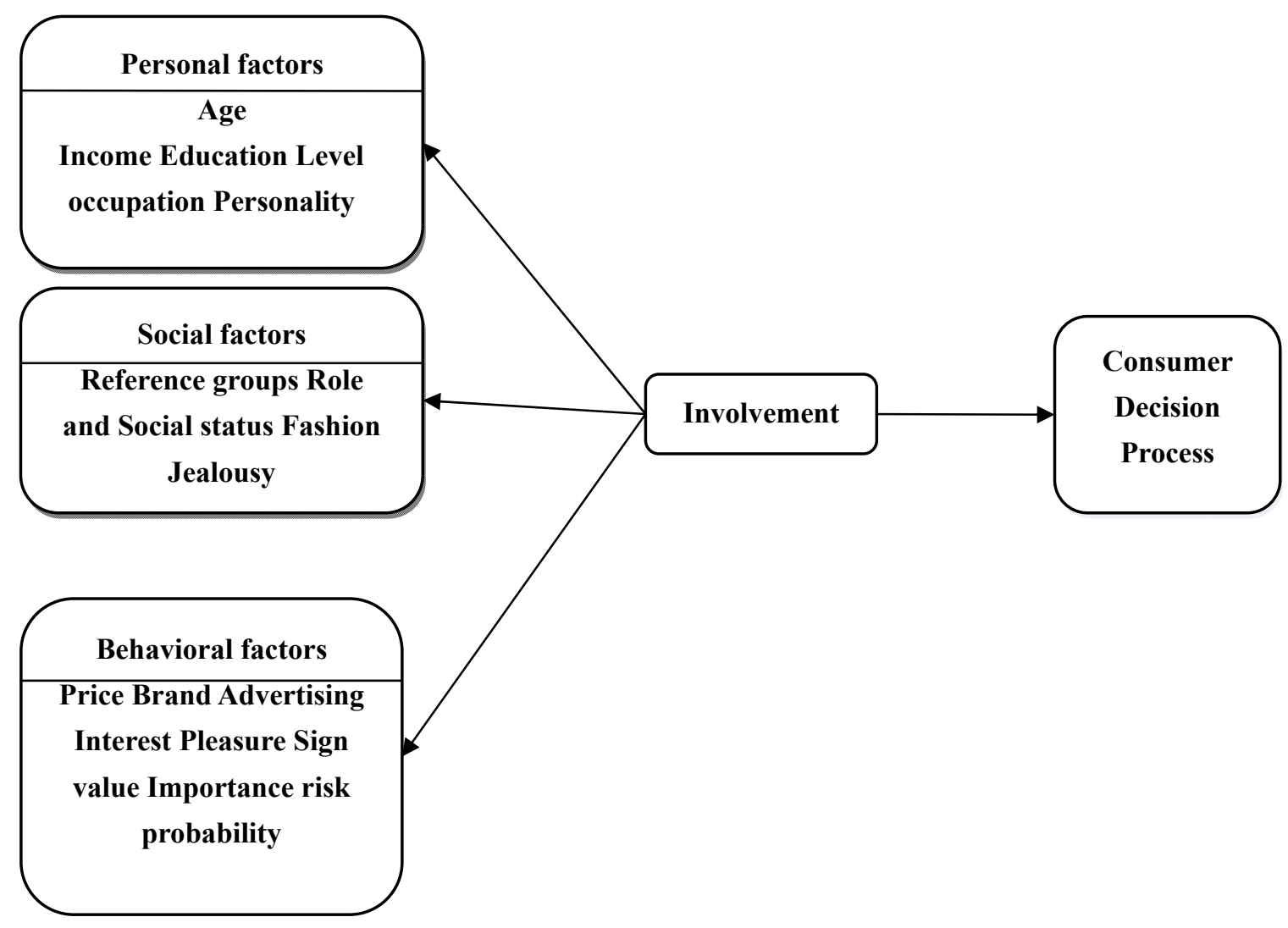

Figure 1. Conceptual model

\section{H1-2: the social factors influence the consumer purchase process positively.}

Behavioral factors: the individual's choice is influenced by four psychological factors that include motivation, perception, learning, and believes (Kotler, 1988). Each of these factors entered to the black box for different analysis. Also an individual's purchase behavior is the results of complex and mutual effect of social, cultural, personal, and mental factors. From psychological perspective, product price influences purchase type and tendency and also it has effective role in the product involvement. This means that the consumer's involvement is more in the higher price products than lower price ones (Laurent \& Kapferer, 1985; Traylor \& Joseph, 1984). The advertisement strategies depend on the consumer's involvement level in every product class (Laurent, \& Kapferer, 1985; Ray, 1982; Rothschild, 1979; Vaughn, 1980). The empirical findings indicate that the factors such as attitudes and brand loyalty have effective role in creating involvement in product choice (Foxall, Goldsmith, \& Brown, 1998). A brand value and involvement in the product purchase is effective in the product evaluation by consumer (Parkvithee $\&$ Miranda, 2012). The involvement level can be related to the media type and the consumer's behaviors in the purchase decision (Josiam, Kinley, \& Kim, 2005; Huang, Chou, \& Lin, 2010). A product involvement is sustainable and also is related to the personal factors, needs, interests, and its values (Marshall \& Bell, 2004).

Kapferer and Laurent (1985) developed the customer involvement profile (CIP) measure using five similar dimensions:

1) Interest: the personal interest an individual has in an object. 
2) Pleasure: the hedonic or emotional appeal or pleasure an individual derives from an object.

3) Sign value: the extent to which an object reflects or expresses the individuals self.

4) Importance risk: the perceived importance of the negative consequences of making a bad purchase.

5) Risk probability: the perceived probability of making a bad purchase.

H1-3: the behavioral factors influence the consumer purchase decision positively.

\section{Data and Results}

\subsection{Data-collecting Instrument}

The statistical population of this study includes the customers that have purchased from BALL chain stores in the city of Isfahan. In order to calculate the sample size, Kokran table of sampling has been used. A sample of 30 customers was selected for this study randomly and then a questionnaire has been used to select the data. These questionnaires have been distributed among the customers and 277 of them were indicated by them. This questionnaire includes three sections that were developed based on the Likert five-point scale in which 1 is strongly disagreeing and 5 is strongly agree. The first section of this questionnaire includes several questions about involvement. This includes personal, social, and behavioral factors that each of them consists of different sub-factors. The second section is about consumer decision process (CDP). The SPSS20 and AMOS are the statistical software that used for analyzing the data.

\subsection{Reliability and Validity of the Questionnaire}

Content validity: because the questionnaire has been developed based on the literature and previous studies review and also because it has been reviewed and modified by academic experts, its validity is confirmed.

Table 1. Cronbach's alpha coefficient

\begin{tabular}{ll}
\hline Variables & Cronbach's alpha coefficient \\
\hline Personal factors & $\mathbf{0 . 8 3}$ \\
Social factors & 0.72 \\
Behavioral factors & 0.88 \\
CDP & 0.91 \\
Total & $\mathbf{0 . 8 5}$ \\
\hline
\end{tabular}

Reliability: the most common test for examining reliability of the questionnaire is Cronbach's Alpha coefficient. This coefficient unusually is used for the questions with multi-scale classes. In order to measure the questionnaire reliability, Cronbach's Alpha has been used that its coefficient is 0.81 . Also this coefficient is 0.83 for personal factors, 0.72 for social factors, and 0.88 for behavioral factors (Table 1).

\subsection{Measuring Instrument}

Personal factors: these include age (Ocass, 2000), income (Pentecost \& Andrews, 2010; Gbadamosi, 2009), educational level, occupation, and personality. These criterions were asked through five questions in Likert five-point scale.

Social factors: these factors were measured through four sub-factors. Reference groups or opinion leaders (Tammy, Bharath, \& Fallon, 2010; Tejavibulya \& Eiamkanchanalai, 2011), social role and status, mode (Summers, Belleau, \& Xu, 2006; Ocass, 2000), and jealously are the social factors that have been examined in our study. Each of these factors has been measured through a question.

Behavioral factors: these factors have been examined through eight criterions. Three of these factors include product price, brand, and advertisement (Foxall et al., 1998; Laurent \& Kapferer, 1985; Traylor \& Joseph, 1984; Ray, 1982; Vaughn, 1980; Josiam, Kinley, \& Kim, 2005). The five remaining factors have been adopted from Laurent and Copfer (1985) study that includes interest, pleasure, sign, risk importance, and risk probability. All of these variables have been examined through eight questions in the Likert five-point scale.

\section{Results}

Descriptive findings and correlation coefficient: the descriptive findings of this study and also correlation coefficients are resulted from SPSS20.

The descriptive findings in terms of respondents' demographics have been indicated in the Table 2. These 
demographics include age and gender. As the findings indicate, $56.8 \%$ of the respondents were male and $43.2 \%$ of them were female. Also the respondents with 15-25 years old are the main respondent groups that are surveyed in our study.

Table 2. Statistical description of the demographic characteristics of respondents

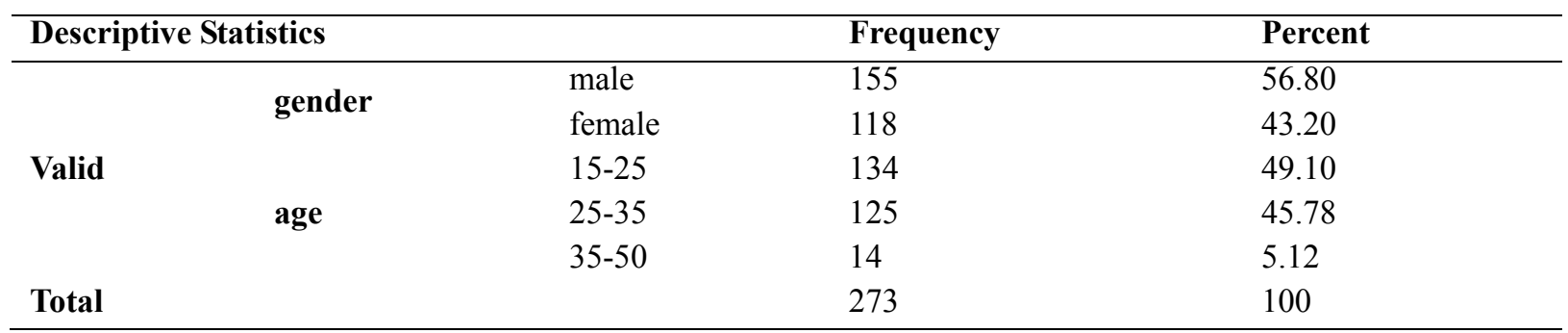

Table 3. Pearson correlations between variables of behavioral factors ${ }^{\mathrm{a}}$ and descriptive statistics

\begin{tabular}{|c|c|c|c|c|c|c|c|c|c|}
\hline & Mean & S.D. & Var. & SKEW & 1 & 2 & 3 & 4 & 5 \\
\hline 1. Personal factors & 3.9 & 0.5 & 0.25 & -0.15 & $\mathbf{1}$ & & & & \\
\hline 2. Social factors & 3.1 & 0.59 & 0.35 & $-\mathbf{0 . 1 7 9}$ & $0.25^{* *}$ & 1 & & & \\
\hline 3. Behavioral factors & 3.4 & 0.42 & 0.18 & 0.34 & 0.10 & $0.15^{*}$ & 1 & & \\
\hline 4. Involvement & 3.4 & 0.35 & 0.13 & 0.3 & $0.34^{w *}$ & $0.225^{* *}$ & $0.31^{\% *}$ & 1 & \\
\hline 5. CDP & 3.8 & 0.49 & 0.24 & -.127 & $0.34^{\pi *}$ & $0.63^{* \pi}$ & $0.65^{* \pi}$ & $0.80^{* *}$ & 1 \\
\hline
\end{tabular}

$* \mathrm{p}<0.05 ; * \mathrm{p}<0.01$.

a: The counted sample number in statistics is 273 . S.D.=standard deviation. Var.= variance. SKEW=skewness.

Table 4. Pearson correlations between variables of personal factors ${ }^{\mathrm{a}}$ and descriptive statistics

\begin{tabular}{lllllllllll}
\hline & Mean & S.D. & Var. & SKEW & 1 & 2 & 3 & 4 & 5 & 6 \\
\hline 1. Age & 4.58 & 0.73 & 0.54 & -2.5 & 1 & & & & & \\
2. Income & 4.62 & 0.71 & 0.50 & -2.28 & 0.12 & 1 & & & \\
3. Education Level & 3.11 & 1.02 & 1.04 & -0.35 & -0.12 & $0.25^{* *}$ & 1 & & \\
4. occupation & 3.53 & 1.11 & 1.23 & -0.25 & 0.18 & $0.15^{* *}$ & $0.19^{* * *}$ & 1 & & \\
5. Personality & 3.94 & 0.90 & 0.81 & -0.99 & 0.08 & -0.03 & $0.20^{* *}$ & $0.26^{* *}$ & 1 & \\
6. CDP & 3.8 & 0.49 & 0.24 & -.127 & $\mathbf{0 . 1 6}$ & $\mathbf{0 . 1 6}$ & $\mathbf{0 . 0 3 6}$ & $\mathbf{0 . 0 8}$ & $\mathbf{0 . 2 8}$ & 1 \\
\hline
\end{tabular}

$* \mathrm{p}<0.05 ; * * \mathrm{p}<0.01$

a: The counted sample number in statistics is 273 . S.D.=standard deviation. Var.= variance. SKEW=skewness.

Table 5. Pearson correlations between variables of social factors ${ }^{\mathrm{a}}$ and descriptive statistics

\begin{tabular}{llllllllll}
\hline & Mean & S.D. & Var. & SKEW & $\mathbf{1}$ & $\mathbf{2}$ & $\mathbf{3}$ & $\mathbf{4}$ & $\mathbf{5}$ \\
\hline 1. Reference groups & 3.4 & $\mathbf{0 . 9 7}$ & $\mathbf{0 . 9 5}$ & $\mathbf{- 0 . 7 8}$ & $\mathbf{1}$ & & & & \\
2. Role and Social status & 3.7 & $\mathbf{0 . 9 1}$ & $\mathbf{0 . 8 3}$ & $\mathbf{- 0 . 6 7}$ & $\mathbf{0 . 2 9}$ & $\mathbf{1}$ & & & \\
3. Fashion & 3.4 & $\mathbf{1 . 0}$ & $\mathbf{1 . 1 7}$ & $\mathbf{- 0 . 6 5}$ & $\mathbf{- 0 . 0 1}$ & $\mathbf{0 . 0 1}$ & $\mathbf{1}$ & & \\
4. Jealousy & $\mathbf{2 . 1}$ & $\mathbf{1 . 1 2}$ & $\mathbf{1 . 2 7}$ & $\mathbf{0 . 7}$ & $\mathbf{- 0 . 0 1}$ & $\mathbf{0 . 0 6}$ & $\mathbf{0 . 2 9}$ & $\mathbf{1}$ & \\
5. Consumer Decision Process & $\mathbf{3 . 8}$ & $\mathbf{0 . 4 9}$ & $\mathbf{0 . 2 4}$ & $\mathbf{- . 1 2 7}$ & $\mathbf{0 . 1 2}$ & $\mathbf{0 . 0 9}$ & $\mathbf{- 0 . 0 2}$ & $\mathbf{0 . 0 4}$ & 1 \\
\hline
\end{tabular}

*p $<0.05 ; * * \mathrm{p}<0.01$.

a: The counted sample number in statistics is 273 . S.D.=standard deviation. Var.= variance. SKEW=skewne

In order to analyze the effect of the independent factors on the dependent factors, it is necessary to calculate the relationships between them. Correlation coefficient was used for this purpose. The results of correlation coefficient indicate that there are significant relationships between all of the variables except the relationship between behavioral and personal factors $(\mathrm{p}<0.01, \mathrm{p}<0.05)$. Also the results indicate that there are significant 
relationships between involvement, social factors, behavioral factors, and consumer decision process $(p<0.01)$. These results are indicated in the table 3. Also table 4 shows the correlations between personal factors components. Based on this table, all of the relationships were confirmed except educational level and occupation $(\mathrm{p}<0.01)$. On the other hand, table 5 shows the correlations between social factors components and only the correlation with reference groups is confirmed. Table 6 shows the correlations between behavioral factors components this Table indicates that the correlations between components and consumer decision process is significant only between price, risk importance, and risk probability $(\mathrm{p}<0.01, \mathrm{p}<0.05)$.

Fitness criterions and examining the relationship between factors: the fit criterions have been resulted from AMOS.

Table 6. Pearson correlations between variables of behavioral factors ${ }^{\mathrm{a}}$ and descriptive statistics

\begin{tabular}{|c|c|c|c|c|c|c|c|c|c|c|c|c|c|}
\hline & Mean & S.D. & Var. & SKEW & 1 & 2 & 3 & 4 & 5 & 6 & 7 & 8 & 9 \\
\hline 1. Price & 2.5 & 1.17 & 1.38 & 0.65 & 1 & & & & & & & & \\
\hline 2. Brand & 2.5 & 1.08 & 1.18 & 0.51 & $0.22^{* *}$ & 1 & & & & & & & \\
\hline 3.Advertising & 3.03 & 1.08 & 1.19 & -0.85 & 0.08 & 0.06 & 1 & & & & & & \\
\hline 4. Interest & 4.0 & 0.60 & 0.35 & -0.85 & 0.09 & $0.41^{* *}$ & -0.01 & 1 & & & & & \\
\hline 5. Pleasure & 4.2 & 0.65 & 0.42 & -0.88 & 0.04 & $0.26^{* *}$ & $-0.18^{* *}$ & $.34^{* * *}$ & 1 & & & & \\
\hline 6. Sign value & 3.8 & 0.82 & 0.67 & -0.57 & 0.01 & $0.13^{*}$ & 0.04 & $0.31^{* * *}$ & $0.28^{* * *}$ & 1 & & & \\
\hline 7. Importance risk & 4.1 & 1.1 & 1.1 & -1.19 & 0.09 & -0.01 & 0.12 & $0.288^{* *}$ & 0.09 & 0.16 ** & 1 & & \\
\hline 8. Risk probability & 3.01 & 1.25 & 1.56 & 0.02 & 0.11 & $0.13^{*}$ & 0.02 & -0.020 & 0.011 & $-0.22^{* *}$ & $-0.24^{* *}$ & 1 & \\
\hline 9. CDP & 3.8 & 0.49 & 0.25 & -0.15 & 0.11 & $0.18^{* *}$ & $0.15^{*}$ & $0.20^{* * *}$ & $0.13^{*}$ & $0.33^{* *}$ & 0.07 & 0.07 & 1 \\
\hline
\end{tabular}

$* \mathrm{p}<0.05 ; * * \mathrm{p}<0.01$

a: The counted sample number in statistics is 273 . S.D. $=$ standard deviation. Var.= variance. SKEW=skewness

Table 7. The overall fit index the comprehensive model of research

\begin{tabular}{lll}
\hline Goodness-of-fit indices & Reference value & Construct \\
\hline /df $2 \chi$ & $/ \mathrm{df}<52 \chi$ & 3.359 \\
0.988 & $\mathrm{GFI}>0 / 90$ & GFI \\
0.941 & $\mathrm{AGFI}>0 / 90$ & AGFI \\
0.093 & $\mathrm{RMSEA}<0 / 1$ & RMSEA \\
0.940 & $\mathrm{CFI}>0 / 90$ & $\mathrm{CFI}$ \\
0.920 & $\mathrm{NFI}>0 / 90$ & NFI \\
0.943 & $\mathrm{IFI}>0 / 90$ & IFI \\
\hline
\end{tabular}

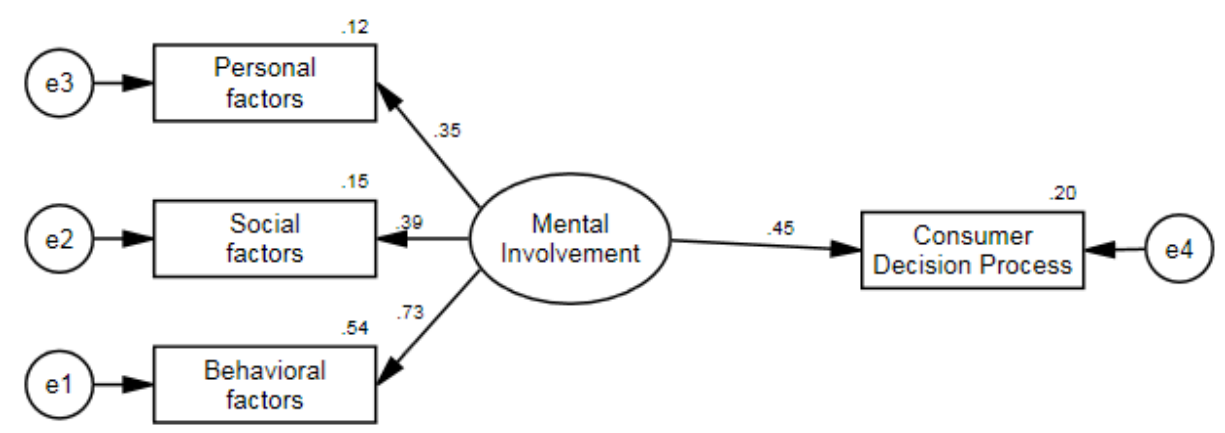

Figure 2. Measurement model of research

The fitness criterions are the most important steps in the analysis of structural equation modeling. These criterions are used to answer the question that whether the model is confirmed by the collected data or not. These criterions have been indicated in the Table 7. As these results indicate, all of the fitness criterions are favorable and show that the model is a good one. 
Also the structural equation modeling and confirmatory factor analysis have been shown for research variables. The Beta coefficient in the modified model indicates that the involvement effect on the consumer purchase process is 0.45 . This means that $45 \%$ of the consumer purchase process variances are explainable by consumer involvement (Figure 2).

Examining the relationship between variables: the AMOS outputs in the modified model show that sig is 0.01 and this indicates that the main hypothesis about the effect of involvement on the consumer decision process is confirmed. These results have been indicated in the Table 8 .

Table 8. AMOS output for the modified model

\begin{tabular}{llllll}
\hline & Path main hypothesis & Standard estimate & Standard error & Ratio critical & Sig. \\
\hline Mental involvement & Consumer Decision Process & 0.451 & 0.148 & 3.667 & 0.00 \\
\hline
\end{tabular}

Also the effect of involvement components on the consumer decision process is examined in the Figure 3 . The AMOS outputs that are indicated in the table 9 show that sig is 0.002 and this indicates that the behavioral factors influence the consumer decision making. Therefore, the firth and third hypotheses have been confirmed. Also it is should be remembered about second hypothesis that the significant level of social factors effect on the consumer decision process is more than 0.05 and this indicates that social factors does not influence the consumer decision process. So the second hypothesis is not confirmed.

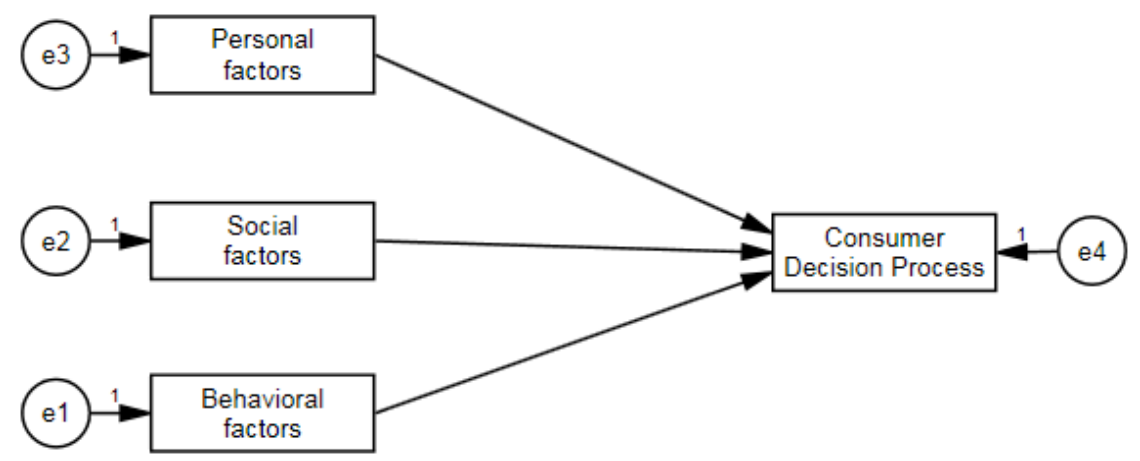

Figure 3. Mental involvement dimensions on the consumer decision process

Table 9. AMOS output for sub hypothesis

\begin{tabular}{lll}
\hline & Path sub-hypotheses & Sig. \\
\hline Personal Consumer Decision Process & factors & 0.002 \\
Social Consumer Decision Process & factors & 0.658 \\
Behavioral Consumer Decision Process & factors & 0.00 \\
\hline
\end{tabular}

\section{Discussion and Conclusion}

The present study seeks to examine the effect of involvement on the consumer decision process. In this study, involvement includes individual, social, and behavioral factors. The statistical population includes the customers that have purchased from BALL chain stores in the city of Isfahan in 2013. A sample of 300 customers has been selected for survey through random sampling method. Data-collecting instrument is a questionnaire. The results of correlation coefficient in the SPSS indicate that the age as one of the involvement factors influence the consumer purchase process positively and because the young respondents with 15-25 years old are the main respondent group in our study, it is resulted that involvement among young customers influence their purchase decisions more than old ones. These results are consistence with previous studies. On the other hand, the results indicate that the consumers' income is effective in creating involvement and so this factor has significant positive effect. In other words, if the consumers' income is high their purchases will be complex that has effect on their involvement and purchase decisions (Gbadamosi, 2009). Also the results indicate that the customers' personality characteristics have significant positive effect on their decision making process. Personality as set of the fixed behaviors in the human life can be effective in the individuals' involvement and purchase type. Other personality 
factors such as educational level and occupation had not significant effect on the purchase decisions. Finally, the AMOS outputs indicate that the personality factors influence purchase process.

As indicated in the previous sections, social factors have been examined through several sub-factors such as reference groups, social role and status, mode, and jealously that only the effect of reference groups was significant. On the other hand, it is should be considered that because the consumers facing different classes of products in the market and also have not complete awareness about some of them, they listen to the opinion leaders' preferences and interest (Tammy, Bharath, \& Lockett, 2010; Tejavibulya \& Eiamkanchanalai, 2011). Also with respect to the effects of modes among different genders on creating involvement (Ocass, 2000), unfortunately it is not confirmed in our study. Also the results of regression analysis indicate that jealously is not confirmed in our study and finally the effect of social factors on the consumer decision process is not confirmed.

The results of behavioral factors indicate that some sub-factors such as brand and advertisement is effective in creating involvement type and purchase decisions and this is consistent with the previous results (Josiam, Kinley, \& Kim, 2005; Huang, Chou, \& Lin, 2010). These results indicate that if the customers' loyalty to a brand is high and the products advertisement is sustainable, then leads that the consumer or buyer considers brand and advertisement in his/her decision making process more than other factors. As a result, this involvement influences purchase process positively. Also the sing and value are the main factors that influence purchase process more than other factors in the consumer involvement profile. These factors indicate that how much the purchased product show the buyers' internal characteristics and the results of regression test indicate that behavioral factors influence the customers' decision making process positively.

This study confirms that involvement influences the consumers' decision making process positively and this result is consistent with previous findings (Lin \& Chen, 2006). Regardless of this, our study has some limitations. The first limitation is that our study considers only three effective factors on involvement creation, but there are other different effective factors on the involvement creation such as cultural factors. The second limitation of this study is sample (chain stores customers) that may is not representative of the population. Therefore, it is suggested that the future studies concentrate on the other effective factors on involvement creation (such as cultural factors) and identify and consider them. Also if the future studies can be implemented at international level, it is possible to compare their results to acquire better results.

\section{References}

Broderick, A., \& Mueller, R. (1999). A theoretical and empirical exegesis of the consumer involvement construct: The psychology of the food shopper. Journal of Marketing Theory and Practice, 7(4), 97-108.

Engel, J. F., Blackwell, R. D., \& Miniard, P. W. (1993). Consumer Behavior (7th ed.). Dryden Press, Chicago, IL.

Engel, J. F., Blackwell, R. D., \& Miniard, P. W. (1993). Consumer Behavior (7th ed.). Dryden Press, Chicago, IL.

Foxall, G., Goldsmith, R., \& Brown, S. (1998). Consumer Psychology for Marketing (2nd ed.). International Thomson Business Press, Boston, MA.

Gbadamosi, A. (2009). Low-income consumers' reactions to low-involvement products. Marketing Intelligence \& Planning, 27(7), 882-899. http://dx.doi.org/10.1108/02634500911000207

Goldsmith, R. E. (2002). Explaining and predicting consumer intention to purchase over the internet: An exploratory study. Journal of Marketing Theory and Practice, 10(2), 22-28.

Houston, M. J., \& Rothschild, M. L. (1978). Conceptual and Methodological Perspectives in Involvement (pp. 184-187). Research Frontiers in Marketing: Dialogues and Directions, Chicago: American Marketing Association.

Huang, C. Y., Chou, C. J., \& Lin, P. C. (2010). Involvement theory in constructing bloggers' intention to purchase travel products. Tourism Management, 31, 513-526. http://dx.doi.org/10.1016/j.tourman.2009.06. 003

Josiam, B., Kinley, T., \& Kim, Y. (2005). Involvement and the tourist shopper: Using the involvement construct to segment the American tourist shopper at the mall. Journal of Vacation Marketing, 11(2), 135-154. http://dx.doi.org/10.1177/1356766705052571

Kim, J. K., Kim, W. J., \& Park, S. C. (2010). Consumer perceptions on web advertisements and motivation factors to purchase in the online shopping. Computers in Human Behavior, 26, 1208-1222. http://dx.doi.org/ 10.1016/j.chb.2010.03.032 
Kotler, P. (1988). Marketing management: Analysis, planning, implementation and control. New Jersey: Prentice Hall.

Kuenzel, J., \& Musters, P. (2007). Social interaction and low involvement products. Journal of Business Research, 60, 876-883. http://dx.doi.org/10.1016/j.jbusres.2007.02.008

Laurent, G., \& Kapferer, J. (1985). Measuring consumer involvement profiles. Journal of Marketing Research, 22(2), 41-53. http://dx.doi.org/10.2307/3151549

Lianga, Y. P. (2012). The Relationship between Consumer Product Involvement, Product Knowledge and Impulsive Buying Behavior. Procedia-Social and Behavioral Sciences, 57, 325-330. http://dx.doi.org/ 10.1016/j.sbspro.2012.09.1193

Lin, L. Y., \& Chen, C. S. (2006). The influence of the country-of-origin image, product knowledge and product involvement on consumer purchase decisions: An empirical study of insurance and catering services in Taiwan. Journal of Consumer Marketing, 23(5), 248-265. http://dx.doi.org/10.1108/07363760610681655

Maoz, E., \& Tybout, A. M. (2002). The moderating role of involvement and differentiation in the evaluation of brand extensions. Journal of Consumer Psychology, 12(2), 119-131. http://dx.doi.org/10.1207/S15327663 JCP1202_05

Marshall, D., \& Bell, R. (2004). Relating the food involvement scale to demographic variables, food choice and other constructs. Food Quality and Preference, 15, 871-879. http://dx.doi.org/10.1016/j.foodqual.2004. 06.003

Mittal, B. (2004). Lack of attribute search ability: Some thoughts. Psychology and Marketing, 21(6), 443-462. http://dx.doi.org/10.1002/mar.20013

Ocass, A. (2000). An assessment of consumers' product, purchase decision, advertising and consumption involvement in fashion clothing. Journal of Economic Psychology, 21, 545-576. http://dx.doi.org/10.1016 /S0167-4870(00)00018-0

Parkvithee, N., \& Miranda, M. J. (2012). The interaction effect of country-of-origin, brand equity and purchase involvement on consumer purchase intentions of clothing labels. Asia Pacific Journal of Marketing and Logistics, 24(1), 7-22. http://dx.doi.org/10.1108/13555851211192678

Pentecost, R., \& Andrews, L. (2010). Fashion retailing and the bottom line: The effects of generational cohorts, gender, fashion fanship, attitudes and impulse buying on fashion expenditure. Journal of Retailing and Consumer Services, 17, 43-52. http://dx.doi.org/10.1016/j.jretconser.2009.09.003

Puccinelli, N. M., Goodstein, R. C., Grewal, D., Price, R., Raghubir, P., \& Stewart, D. (2009). Customer Experience Management in Retailing: Understanding the Buying Process. Journal of Retailing, 85(1), 15-30. http://dx.doi.org/10.1016/j.jretai.2008.11.003

Ray, M. L. (1982). Advertising and Communication Management (p. 20). Englewood Cliffs, NJ: Prentice Hall, Inc.

Rothschild, M. L. (1984). Perspective on involvement: Current problems and future directions. In T. C. Kinnear (Ed.), Advances in Consumer Research (Vol.11, No.1, pp. 216-217).

Sengupta, J., \& Fitzsimons, G. J. (2004). The effect of analyzing reasons on the stability of brand attitudes, a reconciliation of opposing predictors. Journal of Consumer Research, 31(3), 705-711. http://dx.doi.org/10. $1086 / 425105$

Shamdasani, P. N., Stanaland, A. J. S., \& Tan, J. (2001). Location, location, location, insights for advertising placement on the web. Journal of Advertising Research, 41(4), 7-21.

Summers, T. A., Belleau, B. D., \& Xu, Y. (2006). Predicting purchase intention of a controversial luxury apparel product. Journal of Fashion Marketing and Management, 10(4), 405-419. http://dx.doi.org/10.1108/136 12020610701947

Tammy, R. K., Bharath, M. J., \& Fallon L. (2010). Shopping behavior and the involvement Construct. Journal of Fashion Marketing and Management, 14(4), 562-575. http://dx.doi.org/10.1108/13612021011081742

Tejavibulya, P., \& Eiamkanchanalai, S. (2011). The Impacts of Opinion Leaders towards Purchase Decision Engineering under Different Types of Product Involvement. Systems Engineering Procedia, 2, 12-22. http://dx.doi.org/10.1016/j.sepro.2011.10.003

Traylor, M., \& Joseph, W. (1984). Measuring consumer involvement in products: Developing a general scale. 
Psychology \& Marketing, 1(2), 65-77. http://dx.doi.org/10.1002/mar.4220010207

Vaughn, R. (1980). How Advertising Works: A Planning Model. Journal of Advertising Research, 20, 27-33.

Zaichkowsky, J. L. (1985). Measuring the Involvement Construct. Journal of Consumer Research, 12(3), 341-352. http://dx.doi.org/10.1086/208520

Zaichkowsky, J. L. (1986). Conceptualizing involvement. Journal of Advertising, 15(2), 4-14-34.

\section{Appendix A}

Table A1. Construct items, mean and standard deviation

\begin{tabular}{|c|c|c|c|c|}
\hline Item & & & Mean $^{\mathrm{a}}$ & SD \\
\hline \multirow{5}{*}{$\begin{array}{l}\text { Personal } \\
(\alpha=0.83)\end{array}$} & $\mathrm{X}_{1}$ & $\begin{array}{l}\text { When I want to buy a gift for my friend, I consider his/her } \\
\text { age. }\end{array}$ & 4.58 & 0.73 \\
\hline & $\mathrm{X}_{2}$ & My income has effective role in my purchase decisions. & 4.62 & 0.71 \\
\hline & $\mathrm{X}_{3}$ & $\begin{array}{l}\text { My educational level leads more scrupulosity in my } \\
\text { purchases. }\end{array}$ & 3.11 & 1.02 \\
\hline & $\mathrm{X}_{4}$ & My occupation is effective in my purchases. & 3.53 & 1.11 \\
\hline & $\mathrm{X}_{5}$ & I consider my personality characteristics in my purchases. & 3.94 & 0.90 \\
\hline \multirow{4}{*}{ Social factors $(\alpha=0.72)$} & $\mathrm{X}_{6}$ & $\begin{array}{l}\text { My family, friends, and opinion leader's viewpoints have } \\
\text { effective role in my purchases. }\end{array}$ & 3.4 & 0.97 \\
\hline & $\mathrm{X}_{7}$ & $\begin{array}{l}\text { My social status and role among different group members } \\
\text { have effect on my purchases. }\end{array}$ & 3.7 & 0.91 \\
\hline & $\mathrm{X}_{8}$ & I attend the prevalent modes in my life environment. & 3.4 & 1.0 \\
\hline & $\mathrm{X}_{9}$ & The jealously has effective role in my purchases. & 2.1 & 1.12 \\
\hline \multirow{7}{*}{$\begin{array}{l}\text { Behavioral } \\
(\alpha=0.88)\end{array}$} & $\mathrm{X}_{10}$ & I spend more time for expensive products. & 2.5 & 1.17 \\
\hline & $\mathrm{X}_{11}$ & I have much sensitivity and loyalty on my favorite brands. & 2.5 & 1.08 \\
\hline & $\mathrm{X}_{12}$ & $\begin{array}{l}\text { A product has effective role in my choices, if many } \\
\text { advertisements have been done about it. }\end{array}$ & 3.03 & 1.08 \\
\hline & $\mathrm{X}_{13}$ & $\begin{array}{l}\text { I consider some products important and more interesting than } \\
\text { other ones. (source: Laurent and Kapferer, 1985) }\end{array}$ & 4.0 & 0.60 \\
\hline & $\mathrm{X}_{14}$ & $\begin{array}{l}\text { I enjoy some products purchasing. (source: Laurent and } \\
\text { Kapferer, 1985) }\end{array}$ & 4.2 & 0.65 \\
\hline & $\mathrm{X}_{15}$ & $\begin{array}{l}\text { The product that I purchase, show my internal characteristics } \\
\text { relatively. (source: Laurent and Kapferer, 1985) }\end{array}$ & 3.8 & 0.82 \\
\hline & $\mathrm{X}_{16}$ & $\begin{array}{l}\text { It is uneasy for me to purchase a product that is defect or } \\
\text { unsuitable for me. (source: Laurent and Kapferer, 1985) }\end{array}$ & 4.1 & 1.1 \\
\hline \multirow{7}{*}{$\begin{array}{l}\text { Consumer Decision } \\
\text { Process }(\alpha=0.91)\end{array}$} & $\mathrm{X}_{17}$ & I do not my purchases with full confidence. & 3.01 & 1.25 \\
\hline & $\mathrm{Y}_{1}$ & $\begin{array}{l}\text { The internal and external needs and motivations lead that I } \\
\text { think about purchase. }\end{array}$ & 3.74 & 0.868 \\
\hline & $\mathrm{Y}_{2}$ & $\begin{array}{l}\text { I use different informational resources (such as friends) } \\
\text { before purchase it. }\end{array}$ & 3.93 & 0.94 \\
\hline & $\mathrm{Y}_{3}$ & I evaluate different brands of a product. & 3.74 & 1.01 \\
\hline & $\mathrm{Y}_{4}$ & $\begin{array}{l}\text { I consider other people's viewpoints during my purchase } \\
\text { time. }\end{array}$ & 3.64 & 0.94 \\
\hline & $\mathrm{Y}_{5}$ & $\begin{array}{l}\text { It may that some unpredicted situational factors influence my } \\
\text { purchase decision and I cancel my purchase. }\end{array}$ & 3.82 & 0.92 \\
\hline & $\mathrm{Y}_{6}$ & I think about product satisfaction after its purchase. & 3.96 & 1.01 \\
\hline
\end{tabular}

${ }^{a}$ Scale was rated from 1 to 5.

\section{Copyrights}

Copyright for this article is retained by the author(s), with first publication rights granted to the journal.

This is an open-access article distributed under the terms and conditions of the Creative Commons Attribution license (http://creativecommons.org/licenses/by/3.0/). 